\title{
PENGARUH KARAKTERISTIK TIM, PENGETAHUAN MANAJEMEN, DAN ETIKA KERJA TERHADAP KINERJA KETUA PROGRAM STUDI PADA SEKOLAH TINGGI ISLAM SWASTA DI PROVINSI JAMBI
}

\author{
Ahmad Ridwan \\ Institut Agama Islam Negeri Sulthan Thaha Saifudin Jambi \\ ahmadridwan1474@yahoo.com
}

\begin{abstract}
The objective of the research is to obtain information concerning the effect of team characteristics, management knowledge, and job ethics, on heads of study program performance. The research was carried out by means of survey in Jambi Province, involving 75 heads of study program as respondents who are selected through simple randomsampling and the data has been analysed by path analysis after all variables put into thecorrelation matrix. (1) there is a direct effect of team characteristics on heads of studyprogram performance.(2) there is direct effect management knowledge on heads of studyprogram performance. (3) there is a direct effect job ethics on heads of study programperformance . (4) there is a direct effect of team characteristics on job ethics, and (5) there is a direct effect management knowledge on job ethics. Therefore, the variation ofheads of study program performance are effected by the variation of team characteristics, variation management knowledge, variation job ethics.
\end{abstract}

Keywords: team characteristics, management knowledge, job ethics and headsof study program performance.

\section{PENDAHULUAN}

Sangat dirasakan pentingnya kebutuhan lulusan perguruan tinggi yang mempunyai paradigma global dengan jatidiri bangsa Indonesia serta memiliki kemampuan membangun jaringan kerja yang luas. Tuntutan normatif yang begitu tinggi terhadap pendidikan, khususnya pendidikan tinggi, menunjukkan betapa pentingnya misi pendidikan tinggi. Sebagai subsistem dari sistem pendidikan nasional, perguruan tinggi mengemban misi untuk mengembangkan seluruh kepribadian manusia melalui kekuatan penalaran individu sebagai salah satu kekuatan utamanya, sehingga kelulusannya akan memiliki intellectual lintellegence, emotional intellegence, dan spiritual intelligence, secara sinergi

Berbagai kegagalan terjadi dalam menciptakan sistem, kurikulum, dan metode pendidikan moral dan etika yang terintegrasi, konsisten, dan terpadu dengan disiplin ilmu pengetahuan yang hendak diajarkan; mencakup di 
semua jenis pendidikan formal khsusunya di pendidikan tinggi. Tantangan yang demikian, maka sudah sepatutnya pergruan tinggi memiliki sumber daya manusia yang tidak saja profesional tetapi juga bermutu yang dapat membangun kepercayaan masyarakat untuk bersama-sama menghadapi persoalan yang semakin kompleks. Agar perguruan tinggi dapat bertahan dan bersaing, pengelola harus memiliki pengetahuan yang dapat meningkatkan kualitas pengelola, yakni pengelolaan perguruan tinggi yang kreatif, inovatif, dan mempunyai kewirausahaan yang berorientasi papa service, interpendensi, fokus pada kebutuhan, kolaboratif, dan koordinatif. Untuk dapat memperoleh hal tersebut, banyak factor yang harus dibenahi seperti peningkatan kualitas diri, baik yang menyangkut kognitif maupun efektif. Jadi perhatian khusus kualitas pengelola sebagai pelaksana utama dalam proses pendidikan, karena kualitas lulusan akan banyak ditentukan oleh kualitas pengelolanya, yaitu pimpinan.

Sejalan dengan kontek di atas, Soedjiarto (2008), menjelaskan bahwa darma pendidikan yang dilaksanakan dalam lingkungan pendidikan tinggi belum mampu menjadi wahana pembudayaan kemampuan, nilai, dan sikap dalam rangka, mencerdaskan kehidupan bangsa. Kini dunia telah memasuki era globalisasi. Maka wujud implementasi Tri Darma pun perlu disesuaikan. Para penganut globa lisasi memandang era ini sebagai era postindustrial society. Upaya untuk menghasilkan produk dan pelayanan pendidikan tinggi yang berkualitas tidak hanya menjadi tanggung jawab pemerintah dan pimpinan lembaga tetapi mencakup semua karyawan dan tenaga akademik (SDM) yang ada di lembaga tersebut. Hal ini penting menata kembali pendidikan tinggi secara positif dengan membuat kerangka perubahan baik secara individu atau lembaga. Penataan itu bisa dalam bentuk kinerja pimpinan, pelayanan, proses, skill, manusia dan hubungan sosial, atau karakteristik kelompok. Johnson et al (1995), mengungkapkan bahwa staf pada pendidikan tinggi harus memiliki kompetensi dalam rangka memberikan pelayanan yang berkualitas, antara lain, yaitu; 1) Dengan mudah mengkomunikasikan perubahan, 2) Mempunyai berbagai macam talenta, 3) Mampu mempertahankan perspektif makna universitas secara luas, 4) Mempunyai kemampuan bekerja dalam tim, 5) Tidak puas dengan status quo tapi selalu melakukan perubahan, dan 6) Mempunyai kemampuan 
berapresiasi terhadap negara dan pemerintah federal yang memberikan amanat.

Kenyataan yang terjadi pada saat ini sebagaimana dikemukakan Soedijarto (2008), bahwa ketiga Darma Perguruan Tinggi, yang tampaknya tetap berjalan adalah darma pendidikan. Walaupun demikian, kualitas lulusan diukur dari kerjanya, kemampuan intelektual, kreatlvitas, disiplin, karakter serta moralnya belum seperti yang diharapkan. Ini dapat dilihat masih mudahnya sarjana lulusan universitas atau perguruan tinggi dalam melakukan tugas profesionainya, baik dalam bidang hukum, ekonomi, politik, teknik, maupun pendidikan, mengabaikan nilai-nilai moral. Kita menyaksikan betapa banyak kasus permainan uang dankonspirasi politik dalam politik dan penegakan hukum, kebocoran pajak dan maraknya korupsi, dan lekas rusaknya banyak bangunan serta masih belum berkualitasnya proses pembelajaran di berbagai jenis dan jenjang pendidikan dasar dan menengah.

Seharusnya perguruan tinggi harus mempertimbangkan secara matang mengenai perubahan paradigma perguruan tinggi yang mengarah kepada pertimbangan aspek fisikal, infrastruktur, kelembagaan, politik, sosial-ekonomi dan kapital sumber daya manusia (human capital), seiring pelaksanaan Pasal 53 Undang-Undang Nomor 20 Tahun 2003 tentang Sistem Pendidikan Nasional dan Peraturan Pemerintah (PP) Nomor 60 dan 61 Tahun 1999, tentang Perguruan Tinggi sebagai salah satu bentuk badan hukum pendidikan. Dimana sistem PerguruanTinggi nasional harus mampu menjamin kesempatan pendidikan yang adil, peningkatan kualitasmutu akademik serta meningkatkan efesiensi dan kemandirian manajemen Perguruan Tinggi untuk menghadapi tantangan sesuai dengan tuntutan perubahan kehidupan ke depan.

Sekolah Tinggi Islam Swasta (STIS) di Jambi yang memiliki karakteristik yang heterogen baik ekonomi, demografi maupun budaya yang berbeda membentuk keberadaan perguruan tinggi khususnya STIS menjadi suatu lembaga yang dianggap mampu menghasilkan orang-orang yang berkualitas yang dapat diandalkan menjadi tenaga kerja yang siap pakai. Tetapi kenyataannya, lulusan yang dihasilkan hanyalah orang-orang yang telah selesai melewati satu fase pendidikan tanpa memiliki keahlian yang "unggul" yang dapat bersaing untuk merebut lapangan pekerjaan yang 
tersedia. Hal ini karena umumnya STIS Jambi hanya sebagai wadah untuk melanjutkan jenjang pendidikan setelah MA/SMA, bukan sebagai tempat untuk meningkatkan kemampuan/keterampilan yang dapat dijadikan sebagai andalan, selain itu adanya persepsi dengan masuk ke jenjang pergruan tinggi menyebabkan sebagian mereka telah memenuhi persyaratan tertentu memasuki dunia kerja yang tidak begitu mementingkan kualitas yang sebenarnya.

Sependapat dengan itu, Mukhtar (2010) mengemukakan bahwa, persaingan untuk mendapatkan mahasiswa juga memberi andil kepada STIS untuk mengabaikan kualitas yang diajarkan tetapi lebih cenderung kepada kuantitas, karena sebagia besar biaya operasional Sekolah Tinggi Islam Swasta lebih banyak ditopang oleh jumlah mahasiswa yang diterima sehingga menuntut mereka lebih memperhatikan kuantitas, hal ini mengakibatkan juga kemudahan Sekolah Tinggi Islam Swasta untuk melepaskan mahasiswa tanpa proses yang sesuai dengan prosedur akademik.

Selanjutnya, selain faktor eksternal, faktor internal juga tidak kalah pentingnya untuk turut mempengaruhi dimana proses rekruitmen mengabaikan kualitas input, penetapan kuota melebihi nisbah dosen terhadap mahasiswa, rumusan mata kuliah yang tidak sesuai dengan profesionalisme kompetensi lulusan, rekruitmen yang mengabaikan kompetensi dan kemampuan manajerial, dosen yang tidak terampil mengelola kegitan instruksional. Hal ini semua menyebabkan peranan ketua program studi dalam mengelola sistem akademik cenderung acak-acakan.

Fungsi kepemimpinan akan menjadi motor penggerak yang akan mempengaruhi anggota, yaitu para dosen dan pegawai, agar bekerja secara sukarela sehingga mereka mau menampilkan kinerja tinggi untuk mencapai kinerja organisasi yang tinggi pula. Kinerja pimpinan memerlukan kompetensi, karenanya untuk mencapai kinerja yang tinggi, pemimpin harus memiliki karakter khusus yang terkait erat dengan efektivitas dan superioritas dalam pekerjaannya. Potensi kinerja seorang harus disatukan dengan sumber dayanya, kemudian indvidu tersebut harus diberi kesempatan untuk mencapai tujuan organisasi dimana dia berada. Tetapi perilaku berkinerja tinggi bukan saja ditentukan oleh kemampuan (kompetensinya) saja, tetapi 
juga karakteristik tim dan pengetahuan manajemen agar tujuannya berhasil tercapai. Artinya betapapun seseorang yang memiliki kemampuan yang cukup sesuai dengan kebutuhan jabatannya, tetapi jika dia tidak mengetahui karakteristik kelompoknya dan tidak memiliki etika kerja terhadap tugasnya, maka kinerja tinggi tidak akan tercapai.

Karakteristik tim bukan hanya sekedar karakteristik yang sama untuk berbuat, tetapi menuju kepada tanggung jawab baik pada tingkat individual maupun tingkat tim dengan memiliki sistem evaluasi yang dirancang dengan baik dan sistem kerja yang jelas. Kinerja pimpinan memerlukan tim yang memiliki tanggung jawab dan komitmen terhadap tujuan bersama, sehingga hal ini menentukan sebuah kemampuan manajemen bagi pimpinan. Artinya hasil kerja pimpinan yang merupakan hasil dari upaya yang dilakukan kemudian didukung oleh pengetahuan manajemen. Pengetahuan manajemen seseorang pimpinan dapat dilihat sebagai prestasi terhadap tugas atau pekerjaan yang dimiliki pemimpin terhadap pekerjaannya. Prestasi terhadap tugas akan dipengaruhi oleh banyak hal yang berkenaan dengan manajemen seperti, perencanaan (planning), pengorganisasian (organizing), pelaksanaan (leading), dan pengendalian (controling). Pengetahuan manajemen mencerminkan kapasitas individu yang menunjukkan prestasi terhadap pekerjaannya, Hal ini terlihat dalam sikap positip para karyawan terhadap pekerjaannya dan segala sesuatu yang dihadapi di lingkungan kerjanya.

Pemimpin yang berusaha mencapai kinerja yang tinggi akan bekerja dengan sungguh-sungguh, bersemangat, dan menjalin kerjasama yang baik agar tercapai tujuan organisasi serta memiliki keberpihakan terhadap organisasinya. Selain itu memiliki kesadaran untuk menjalankan kegiatannya yang ditunjukkan oleh sikap, nilai, dan kebiasaan-kebiasaan dalam bekerja. Pimpinan program studi di perguruan tinggi yang memiliki keterkaitan psikologis terhadap tugas-tugasnya menunjukkan bagaimana etika kerja terhadap tugas-tugas organisasinya. Dengan demikian mereka akan semakin berkeinginan untuk bertahan dalam perguruan tinggi dan berusaha mensukseskan visi dan misi perguruan tinggi dengan menampilkan kinerja yang tinggi. 
Berdasarkan latar belakang, identifikasi masalah, dan pembatasan masalah, maka perumusan masalah adalah sebagai berikut; 1) Apakah karakteristik tim berpengaruh langsung terhadap kinerja?, 2) Apakah pengetahuan manajemen berpengaruh langsung terhadap kinerja?, 3) Apakah etika kerja berpengaruh langsung terhadap kinerja?, 4) Apakah karaktersitik tim berpengaruh langsung terhadap etika kerja?, dan 5) Apakah pengetahuan manajemen berpengaruh langsung terhadap etika kerja?

\section{TINJAUAN TEORITIS}

\section{Kinerja}

Kinerja (performance) merupakan variabel yang penting dalam masalah prestasi kerja. Colquitt (2009: 19) menjelaskan bahwa Kinerja secara formal didefinisikan sebagai nilai dari serangkaian perilaku pekerja/karyawan yang berkontribusi, baik positif maupun negatif, terhadap pencapaian tujuan organisasi.

Sebelum membicarakan lebih jauh tentang kinerja terlebih dahulu dapat dilihat pada model yang dikemukan oleh Colquitt, LePine and Wesson tersebut, Mohman, West Resnick, dan Lawler (1989: 110) mengungkapkan pengertian kinerja sebagai: "performance means defining the characteristic or the performance, or defining behavior and tasks, or defining the result that are to be achieved, or defining the situations in which a should happen or all the above. "Dengan kata lain, pendefinisian kinerja berarti mendefinisikan karakteristik atau kinerja, atau pendefinisian perilaku dan tugas atau pendefinisian hasil yang diharapkan untuk dicapai, atau mendefinisian situasi dimana ini perlu terjadi atau semua yang tersebut di atas. Pengertian ini mengungkapkan bahwa pengertian kinerja dapat dipahami dari banyak sudut pandang seperti dari perilaku dan tugas, hasil, atau secara menyeluruh.

Armstrong (2006: 7) mendefinisikan, bahwa kinerja merupakan hasil kerja dan tingkah laku. Pengertian kinerja ini mengaitkan antara hasil kerja dengan tingkah laku. Sebagai tingkah laku, kinerja merupakan aktivitas manusia yang diarahkan kepada pelaksanaan tugas organisasi yang dibebankan kepadanya.

Selain itu, Arnold dan Feldman menyatakan bahwa kinerja memperlihatkan seberapa jauh individu tersebut dapat mewujudkan tujuan- 
tujuannya yang konsisten dengan tujuan organisasi. Kinerja juga merupakan perbandingan antara hasil kerja dengan standar atau ukuran tertentu, seperti target, sasaran atau kriteria yang telah ditentukan dan disepakati bersama. Berdasarkan pandangan ini, dapat dikatakan bahwa kinerja merupakan hasil kerja seseorang yang memenuhi standar kinerja dan persyaratan yang telah ditentukan.

Selain itu, Allan Edward Barsky (1989: 120) menyatakan bahwa kinerja memiliki kriteria, yaitu; pengembangan diri, kerja tim, komunikasi, jumlah produk yang dihasilkan, dan keputusan yang dibuat. Pandangan ini, memberikan pengertian yang lebih terarah tentang kinerja, bahwa kinerja berhubungan dengan diri sendiri, orang lain, hasil kerja, dan proses kerja. Orang yang memiliki kinerja tinggi merupakan orang yang senantiasa melakukan pengembangan diri.

Dia berupaya meningkatkan kualitas dirinya agar mampu menangani permasalahan yang dihadapinya. Selain itu, mampu bekerjasama dengan orang lain.

Hal senada seperti yang disarankan Stiffler (2006: 41) bahwa terdapat lima komponen dasar dalam penilian manajemen kinerja yakni ; 1) Menyatakan tujuan, sumber dan danaorganisasi, 2) Ukuran organisasi dan kinerja individu, 3) Penghargaan atasindividu terhadap kinerjanya, 4) Laporan organisasi kemampuan individu, dan 5) Menganalisis organisasi dan strategipenggabungan antara model dan analisis.

Selanjutnya, Gibson, dan Ivancevich (2006: 19) secara khusus mengemukakan bahwa penilaian kinerja yang efektif memerlukan standar, informasi, dan tindakan korektif. Standar dalam evaluasi kinerja adalah spesifikasi yang utama tentang tingkat penerimaan kinerja. Informasi harus tersedia untuk mengukur kinerja pekerjaan nyata dibandingkan dengan standar pekerjaan.

Sementara itu Mathis (2002: 113-114), menyatakan bahwa ada tiga faktor yang mempengaruhi kinerja yaitu; 1) Kemampuan pribadi untuk melakukan pekerjaan tersebut (Ability-A), 2) Tingkat usaha yang dicurahkan (Effort-E), dan 3) Dukungan organisasi (Support-s).

Menurut Robbins (1996: 658), banyak manajer yang memberikan umpan balik kinerja pada karyawan termasuk kegiatan yang tidak disukai. 
Sesungguhnya kalau tidak ditekan oleh kebijakan dan pengawasan organisasi, alasanya yaitu bahwa 1) para manajer sering tidak enak untuk membahas kelemahan kinerja dengan para karyawannya, 2) banyak karyawan cenderung menjadi defensif bila kelemahan mereka ditunjukkan. Pemecahannya adalah jangan mengabaikannya, tetapi melatih para manajer bagaimana menjalankan pertemuan umpan balik lebih efektif.

Newstrom (2007: 137) mengemukakan empat langkah untuk merancang suatu sistem yang mendukung dan memperbaiki kinerja dengan Management by Objective (MBO) yaitu ; 1) Tujuan dan persetujuan pekerjaan (objective setting) karyawan dan, atasannya meninjau deskripsi pekerjaan, serta aktivitas pokok pekerjaan karyawan, 2) Perencanaan aksi (action planning), standar yang spesifik kinerja harus, dikembangkan bersama untuk mencapai tujuan utama, dan 3) Peninjauan kembali secara berkala (periodic reviews) kinerja kelompok dan pribadi, penilaian tahunan (annual evaluation).

Menurut Nelson dan Campbell (2006: 196), kinerja aktual dengan kinerja yang diukur adalah sama. Pengukuran kinerja operasional lebih mudah dibandingkan dengan pengukuran kinerja manajemen, karena ini sangat bergantung pada ketersediaan data. Sistem penilaian kinerja tersebut bermaksud untuk memperbaiki ketepatan kinerja yang diukur dan penambahan kesesuaian dengan kinerja aktual. Tingkat kesesuaian ini yang kemudian disebut dengan penilaian sebenarnya.

Vecchio (1995: 262-265) menyebutkan bahawa penilaian kinerja dapat dilakukan oleh siapapun yang mengetahui dengan baik kinerja dari karyawan secara pribadi yang mana pasti akan mendatangkan kebaikan dan keburukan. Kemungkinan tersebut adalah: 1) Penyelia menilai karyawan mereka, 2) Karyawan menilai sendiri, 3) Anggota tim yang menilai sesamanya, 4) Karyawan menilai atasan mereka, dan 5) Penilaian dari banyak sumber lain (umpan balik $360^{\circ}$ ).

Sehubungan dengan itu Veithzal (2005: 17) menyebutkan bahwa penilaian kinerja (performance appraisal) merupakan proses yang digunakan organisasi untuk mengevaluasi job performance. Jika dikerjakan dengan benar akan memberikan manfaat yang penting bagi karyawan. Dengan tiga 
syarat untuk berkualitasnya penilaian kinerja yakni harus ada input (potensi), proses (pelaksanaan) dan output (hasil).

Sedangkan Griffin (1990: 13-14) menyimpulkan bahwa manajer tingkat menengah (middle managers) merupakan kelompok terbesar dalam organisasi Manajer tingkat menengah meliputi bagian perencanaan, operasional, dan kepala divisi. Manajer tingkat menengah pada prinsipnya bertanggung jawab terhadap pelaksanaan kebijakan dan perencanaan yang dikembangkan oleh manajer tingkat atas (top managers).Tanggung jawab utama yang lain melakukan supervisi dan mengkoordinasikan kegiatankegiatan tingkat menengah ke bawah. Manajer perencanaan memikirkan halhal yang baru, mengawasi mutu, kerusakan peralatan, dan persoalanpersoalan perserikatan pekerja, serta berperan sebagai inovator dalam organisasi.

Dari berbagai teori tentang kinerja pimpinan tingkat menengah sebagaimana yang dikemukakan sebelumnya, dapat didefinisikan bahwa kinerja merupakan untuk kerja yang dicapai pimpinan dalam menjalankan tugasnya sesuai dengan standar dan kriteria yang ditetapkan untuk pekerjaan itu yang terdiri dari aktivitas, antara lain; 1) menyusun program kerja, 2) menetapkan tujuan kerja, 3) melaksanakan efesiensi kerja, dan 4) memberdayakan bawahan.

\section{Karakteristik Tim}

Ivancevich (2008: 259) Berpendapat bahwa Tim (team) adalah kelompok yang cukup matang dengan derajat ketergantungan tertentu di antara anggotanya dan diwarnai dengan adanya motivasi untuk mencapai sebuah sasaran bersama.

Pandangan lain yang dikemukakan oleh Gibson, Ivancevich, dan Donnely (2006: 244) tentang tim yaitu tipe special dari sebuah kelompok yang memiliki sebuah konsistensi dua atau lebih individu dan bertanggung jawab untuk mencapai tujuan dan sasaran.

Schermerhorn (1997: 121) menjelaskan bahwa secara umum tim berkinerja tinggi memiliki beberapa karakteristik, yaitu: tujuan akhir yang jelas dan bernilai, pelaksanaan tugas (task driven), struktur berorientasi hasil, kemampuan dan kecakapan anggota kelompok dalam bekerja keras, iklim 
kolaboratif, standar tinggi keberhasilan, pengakuan dan dukungan pihak luar, pengarahan kuat dan berprinsip.

Karakteristik tim menurut Daft (2010: 395) adalah "One of a leader's most important job is to get the team designed right by considering such characteristics as size, diversity, and interdependence. The quality of team design has a significant impact on the success of team" (satu pekerjaan penting seorang pemimpin yang utama adalah mendesain tim dengan tepat dengan mempertimbangkan karakteristik atau ciri khususnya seperti ukuran (size), keragaman (diversity), dan saling ketergantungan (interdependence). Kualitas desain tim mempunyai dampak signifikan atas kesuksesan tim.

Menurut Luthan (2006), karakteristik tim adalah karakter atau sifat tim yang membedakannya dengan kelompok tradisional. Menurutnya yang membedakan kelompok dengan tim dilihat dari segi kinerjanya. Lebih jauh dijelaskannya karaktersi tim tim meliputi antara lain; 1) Peran kepemimpinan dilakukan bersama, 2) Akuntabilitas tim, merupakan akuntabilitas tim dan akuntabilitas bersama, 3) Tujuan tim bersifat khusus; 4) Kolektifitas, dimana hasil tim merupakan hasil kolektif, 5) Penjelasan masalah, bersifat keterbukaan dan aktif serta melaksanakannya, bukan mendelegasikannya.

Colquit, LePine dan Wesson (2009: 372) tim adalah "Two or people who work interdependently over some time period to accoplish common goals related to some task oriented purpose. "Dua orang atau lebih yang bekerja saling ketergantungan dalam waktu tertentu melengkapi tujuan tertentu yang berhubungan dengan maksud dan beberapa orientasi tugas. Colquit, LePine dan Wesson (2009) kembali menjelaskan karakteristik tim yang dimaksud adalah ciri-ciri khusus yang dapat menggambarkan suatu tim, Karakteristik yang memilki ciri-ciri khusus yaitu, antara lain; 1) Tipe tim yang terdiri dari tim kerja, tim manajemen, tim paralel, tim proyek, dan tim akses. 2) Saling ketergantungan tim, yang terdiri dari saling ketergantungan tugas, saling ketergantungan tujuan, saling ketergantungan sasaran (auto come), 3) Komposisi tim yang terdiri dari peran anggota, kemampuan anggota, kepribadian anggota, perbedaan anggotan, dan ukuran tim. Untuk lebih jelas hal-hal yang dapat menggambarkan tim adalah jenis-jenis tim, perbedaan pada jenis tim, interdependensi tim, komposisi tim, dan efektivitas tim. 
Jenis-jenis Tim. Ada lima jenis umum dari tim dan masing-masing dikaitkan dengan sejumlah karakteristik. Karakteristik-karakteristik yang paling penting mencakup tujuan tim, jangka waktu keberadaan, dan jumlah waktu yang diperlukan oleh para anggota tim, sebagai berikut; 1) Tim Kerja, 2) Tim Manajemen, 3) Tim Paralel, 4) Tim Proyek, dan 5) Tim Kegiatan.

Selanjutnya Ivancevich (2008: 274-277) menjelaskan tentang jenis jenis tim sebagai berikut; 1) Tim Penyelesaian Masalah, 2) Tim Lintas Fungsi (Cross-Functional Team), 3) Tim Maya (Virtual Team), 4) Tim Penelitian dan Pengembangan (Researchand Development Team/R\&D Team) Tim, dan 5) Mandiri (Self-Managed Team).

Perbedaan Pada Jenis-Jenis Tim. Yang menjadi perbedaan jenisjenis tim terdapat pada tahap-tahap perkembangannya sebagaimana yang diungkapkan oleh James A. F. Stoner (1996: 505-506), mengemukakan tahap-tahap perkembangan tim, sebagai berikut; 1) Pembentukan, 2) Konfilk, 3) Pemantapan Norma, 4) Berprestasi, 5) Pembubaran.

Akhirnya untuk kelompok sementara seperti gugus tugas, inilah waktunya kelompok mengakhiri aktivitasnya. Interdependensi Tim. Interdependensi merupakan cara di mana para anggotanya saling dikaitkan satu sama lain, yaitu; 1) Interdependensi Tugas, 2) Interdependensi Tujuan,dan 3) Interdependensi Hasil.

Jenis terakhir dari interdependensi berkaitan dengan bagaimana para anggota dikaitkan satu sama lain hubungan timbal balik dan hasil-hasil yang mereka terima sebagai hasil kerja pada tim tersebut.

Komposisi Tim. Colquitt (2009: 388) mengatakan ada lima aspek komposisi tim yang penting, yaitu: peranan, kemampuan, kepribadian, keragaman, dan ukuran. 1). Peranan Anggota 2). Kemampuan Anggota. 3). Kepribadian Anggota. 4). Keragaman Anggota. Dan 5). UkuranTim.

Efektivitas Tim. Ada beberapa isu penting ketika membicarakan efektivitas tim. Seperti yang dikemukakan oleh Invancevich dkk (2008: 277279), mengatakan ada empat aspek efektivitas tim. 1) Pelatihan (Training). 2) Pemberdayaan, sejalan dengan hak atas informasi, tim-tim harus memiliki wewenang. 3) Penghargaan (Reward).

Berdasarkan uraian di atas dapat disintesiskan bahwa karakteristik tim adalah penilaian ketua pgrogram studi terhadap ciri spesifik tim kerja yang 
ada di program studi untuk mendukung pencapaian tujuan program studi meliputi aspek interaksi, struktur pekerjaan, peran teknis anggota, sasaran bersama, tanggung jawab, sharing nilai kultur, memiliki nilai budaya yang ada (spesifik), sinergi antar anggota.

\section{Pengetahuan Manajemen}

Drucker mengatakan, pengetahuan merupakan hasil pemrosesan informasi dari seseorang, shingga dapat menggiringnya untuk melakukan suatu tindakan atau sesuatu yang dapat membuat orang/lembaga dapat melakukan tindakan yang berbeda dengan lebih efektif. Pleget (1984), membedakan pengetahuan (knowledge) menjadi pengetahuan figuratif (figuratif knowledge) dan pengetahuan operatif (operative konowledge). Pengetahuan relatif sering juga disebut deklaratif (declarative), proporsional (propotional) atau pengetahuan teoritis (the oritical knowledge) yang beruapa pengetahuan intelektual yang bersifat prinsip dan faktual.

Jujun Suriasumantri (1999: 82) mengatakan pengetahuan adalah segala sesuatu yang diketahui mengenai apa yang ada dalam lingkungan di mana ia berada. Pengetahuan disebut sebagai khasanah kekayaan mental secara langsung atau tidak langsung turut memperkaya kehidupan kita. Pengetahuan diperoleh masyarakat berpengaruh kuat pada apa yang mereka ketahui sebelumnya sekaligus memunculkan kembali pengetahuan tersebut. Jadi boleh dikatakan pengetahuan seseorang akan selalu berkembang sekaligus mempengaruhi mentalnya dalam berinteraksi dengan lingkungannya. Pengetahuan, seperti dikatakan oleh Good dan Brophy (1980: 149) termasuk pada aspek kognitif dalam psikologi. Dari berbagai pendapat di atas, maka dapat dijelaskan bahwa belajar dapat memberikan pengaruh besar terhadap perubahan sikap dan perilaku seseorang. Sehingga dapat dipahami bahwa pengetahuan merupakan kebutuhan dasar yang dapat mempengaruhi sikapdan nilai seseorang terhadap sesuatu hal.

Sementara pengetahuan itu diperoleh manusia melalui proses belajar. Hal ini sesuai dengan apa yang kemukakan oleh Bloom (1984) yang menyatakan bahwa dalam proses belajar selalu melibatkan tiga domain, yaitu domain kognitif, domain afektif, dan domain psikomotorik. Lebih lanjut dikatakannya bahwa domain kognitif terdiri dari enam tingkatan, di mana 
tingkatan-tingkatan itu menggambarkan tahapan yang merupakan landasan untuk memasuki tahapan yang berikutnya. Keenam tingkatan tersebut terdiri atas (a) pengetahuan (knowledge), (b) pemahaman (comprehension), (c) penerapan (application), (d) analisis (analysis), (e) sintesis (syntesis), (f) evaluasi (evaluation).

Berdasarkan penjelasan di atas, maka dapat dipahami bahwa pengetahuan merupakan kemampuan tingkat awal dalam domain kognitif hasil belajar yang mengarah pada ingatan. Sebagai perilaku kognitif tingkat awal yang menekankan pada proses mengingat, pengetahuan dapat berupa simbol-simbol verbal, atribut, sifat, hubungan, dan fakta yang dapat diingat dan dikenal kembali. Sehubungan dengan itu Bloom kemudian membagi pengetahuan menjadi tiga tingkat besar, yaitu: (a) pengetahuan akan hal-hal yang khusus, (b) pengetahuan akan cara dan alat untuk berhubungan dengan hal khusus, dan (c) pengetahuan akan ha-hal yang umum dan abstrak dalam bidang tertentu.

Manajemen. Robbins dan Coulter (1999: 37) mengatakan bahwa kegitan manajemen mengacu pada proses mengkoordinasi dan mengintegrasikan kegiatan-kegiatan kerja agar diselesaikan secara efesien dan efektif dengan dan melalui orang lain. Lebih lanjut dikatakan bahwa kalau "proses" menggambarkan fungsi-fungsi yang berjalan terus atau kegiatan-kegiatan utama yang dilakukan oleh para manajer. Lebih lanjut dikemukan bahwa fungsi-fungsi manajemen mencakup merencanakan (planning), mengorganisasikan (organizing), pelaksanaan (leading), dan mengawasi (controlling). Pendapat ini sejalan dengan yang apa yang diungkapkan oleh Griffin (1990: 5) dimana manajemen adalah seperangkat aktivitas yang meliputi; perencanaan, dan pengambilan keputusan, pengorganisasian, pengarahan, dan pengawasn yang diliaksanakan langsung oleh suatu sumber daya organisasi (manusia, uang, benda- benda fisik, dan informasi) dengan tujuan untuk mencapai sedapat mungkin tujuan organisasi yang efektif dan efisien.

Sementara George Terry (1996), menyebutkan bahwa "Management is distinic process consisting of planning, organizing, actuating, and controlling performed to determine and accomplish stated objectives by the use of human being and other resources". Maksudnya manajemen adalah 
merupakan suatu proses khusus yang terdiri dari perencanaan, pengorganisasian, pelaksanaan dan pengawasan yang dilakukan untuk menentukan serta mencapai sasaran yang telah ditentukan melalui pemanfaatan sumber daya manusia dan lainnya.

Menurut Wagner dan Hollenbeck (1999: 49) manajemen adalah sebuah proses perencanaan, pengorganisasian, pengarahan, dan pengawasan perilaku organisasi dalam rangka mencapai tujuan melalui pembagian kerja.

Untuk melakukan pekerjaan dengan baik, ada dua hal yang penting diketahui yaitu; pertama, kinerja manajemen dalam mempertentangkan dan menganalisis hal-hal yang masih membingungkan, dan kedua, kinerja organisasi; yaitu mengukur bagaimana organisasi mengerjakan pekerjaan dengan baik. Menurut Robbins (2001: 5) bahwa organisasi itu adalah untuk mencapai tujuan-tujuan seseorang harus menetapkan tujuan-tujuan tersebut dan alat/cara yang dapat digunakan untuk mencapai tujuan itu. Seseorang yang melakukan kegiatan dalam organisasi itu tidak lain adalah manajemen pengetahuan manajemen menanamkan suatu budaya belajar, jika anggota organisasi yang secara sistematis mengumpulkan pengetahuan yang lain dalam organisasi agar supaya mencapai kinerja yang lebih baik. Organisasi yang gagal menggali mata rantai sumber pengetahuan eksternal selalu mereka menghubungkan diri mereka dengan pemberian tanda penghargaan yang terbatas.

Fayol dalam Robbins (2001: 5) menulis bahwa semua manajer menjalankan lima fungsi manajemen: merencanakan, mengorganisasi, memerintah, mengkoordinasi, dan mengendalikan. Kemudian dari lima fungsi ini diringkas menjadi empat: (1) perencanaan. (2) pengorganisasian. (3) pimpinan. (4) pengendalian.

Akhirnya dapat disintesiskan bahwa pengetahuan manajemen adalah segala sesuatu yang diketahui seseorang berkaitan dengan fakta, istilah, konsep tentang fungsi manajemen yang meliputi pengetahuan tentang konsep perencanaan (planning), pengetahuan tantang konsep pengorganisasian (organizing), pengetahuan tentang memimpin (leading), dan pengetahuan tentang pengendalian (controlling) yang diukur dengan tes. 
Etika Kerja itu merupakan refleksi kritis dan rasional mengenai nilai dan norma moral yang menentukan dan terwujud dalam pola perilaku manusia, baik secara pribadi maupun sebagai kelompok. Dengan demikian, maka etika mengacu pada aturan yang menentukan apa jenis perilaku yang sesuai dan tidak sesuai. Etika juga dapat didefenisikan sebagai studi perilaku benar atau salah, dan bagaimana orang harus membuat keputusan tersebut.

Luthans (2008: 47) mengemukakan bahwa pengaruh kebudayaan terhadap perilaku etika berasal dari keluarga, teman, tetangga, pendidikan, agama, dan media. Pengaruh organisasi terhadap etika berasal dari kodekode etik, model peranan, kebijakan dan praktik, dan sistem ganjaran penghargaan dan hukuman.

Selanjutnya Colquitt (2009: 233) menggambarkan model etika kebijakan empat dimensi menegaskan bahwa perilaku-perilaku beretika berasal dari jenjang bertingkat yang dimulai dari kesadaran moral, penilaian moral berkelanjutan, dan selanjutnya hasrat moral serta etika perilaku.

Menurut Donnely (1987: 1107), etika yang biasa dikenai menunjuk pada prinsip perilaku yang membedakan antara baik dan buruk serta antara benar dan salah. Para manajer terutama karena kedudukannya, menghadapi berbagai hal yang diakibatkan oleh berbagai keputusan yang dibuatnya. Sependapat dengan pernyataan itu, Corey (2007: 12) menjelaskan bahwa etika merupakan prinsip moral yang diadopsi oleh seorang individu atau kelompok untuk memberikan aturan dalam tindakan yang benar. Begitu juga Philip G. Zimbardo (1980: 270), menyatakan, bahwa etika kerja telah membuat pekerja pria dan wanita hidup lebih baik karena keutamaan (by virtue) dari kegiatan-kegiatan yang dikerjakan.

James A.F. Stoner (1989: 116) menyatakan bahwa secara luas dan sederhana, etika ialah suatu studi tentang bagaimana keputusan-keputusan kita berpengaruh tentang orang banyak. Etika juga suatu studi tentang hak dan kewajiban manusia, tentang aturan-aturan yang dipakai dalam membuat keputusan-keputusan.

Menurut Bertens (1999: 142-146), kata etika dapat diartikan sebagai berikut: (1) nilai dan norma moral yang menjadi pegangan bagi seseorang atau kelompok orang dalam mengatur tingkah lakunya; (2) kumpulan asas atau nilai moral atau yang disebut kode etik; (3) sebagai ilmu yang 
membahas moralitas. Nilai-nilai moral dalam etika kewajiban merupakan suatu imperatif kategoris, yang berarti bahwa nilai moral mewajibkan kita tanpa syarat mewujudkan nilai moral tersebut. Menurut Bertens, yang termasuk sebagai nilai moral tersebut ialah: (1) kejujuran; (2) tanggung jawab; dan (3) kesetiaan. Etika keutamaan itu mempelajari sifat watak manusia yang memiliki empat pokok keutamaan ialah: (1) kebijaksanaan; (2) keberanian; (3) pengendalian diri; serta (4) keadilan.

Menurut Ernawan (2011: 103), etika kerja adalah rumusan penerapan nilai yang berlaku di lingkungannya, dengan tujuan untuk mengatur tata krama aktivitas para karyawan agar mencapai tingkat efisiensi dan produktivitas yang maksimal. Sedangkan menurut Gunnar Myrdal (1990: 9192) mengemukakan, tiga belas sikap yang memadai untuk etika kerja yang tinggi pada seseorang, yaitu: 1) efisien; 2) rajin; 3) teratur, 4) disiplin/tepat waktu; 5) hemat; 6) jujur dan teliti; 7) rasional dalam mengambil keputusan; 8) bersedia menerima perubahan; 9) gesit dalam memanfaatkan kesempatan; 10) energik; 11) ketulusan dan percaya diri; 12) mampu bekerja sama; dan 13) mempunyai visi yang jauh ke depan.

Bertitik tolak pada berbagai pengertian dan teori tersebut di atas, maka disintesiskan bahwa etika kerja adalah nilai dan norma moral yang diterapkan oleh seseorang yang menjadi acuan dan pedoman dalam menjalankan tugas yang terdiri dari beberapa aspek yaitu, efisein, rajin, teratur, disiplin, hemat, jujur dan teliti, rasional mengambil keputusan, bersedia menerima perubahan (terbuka), gesit memanfaatkan peluang (loyalitas), energik, ketulusan dan percaya diri, bekerja sama, dan mempunyai visi.

Mengacu pada berbagai teori yang diuraikan di atas, maka pengaruh variabel penelitian dapat diarahkan sebagai berikut:

\section{Karakteristik Tim dan Kinerja}

Karakteristik tim adalah penilaian Ketua program studi terhadap ciri spesifik suatu tim kerja yang ada di program studi untuk mendukung pencapaian tujuan program studi dengan melaksankan komponenkomponen tertentu yaitu interaksi, struktur pekerjaan, peran teknis anggota, sasaran bersama, tanggung jawab, sharing nilai kultur, memiliki nilai budaya yang ada (spesifik), sinergi antar anggota.Kinerja adalah unjuk kerja yang 
dicapai pimpinan dalam menjalankan tugasnya sesuai dengan standar dan kriteria yang ditetapkan untuk pekerjaan itu.

Sebagai pimpinan di program studi yang memiliki tanggung jawab bukan hanya bagaimana menghantarkan mahasiswa menjadi lulusan yang berkualitas tetapi juga bertanggung jawab kepada yayasan atau pengelola perguruan tinggi, sudah barang tentu mempunyai tantangan yang besar dalam menjalankan tugasnya. Selain itu, keterbatasan yang dimiliki ketua program studi yaitu keterbatasan waktu karena harus memenuhi target pribadi dalam mencapai penghasilan, sebab tidak dapat hanya bekerja di satu tempat, menyebabkan mereka tidak fokus pada tugasnya. Di samping keterbatasan kemampuan intelektualnya, yang disebabkan tidak adanya biaya dan waktu, mengakibatkan prestasi kerjanya secara menyeluruh dapat dikatakan rendah. Berdasarkan uraian tersebut dapat dikatakan bahwa untuk meningkatkan kinerja ketua program studi maka sudah selayaknya seorang ketua program studi harus memiliki karakteristik tim dengan pola manajemen yang bersinergi positif yang memungkinkan organisasi meningkatkan kinerja. Penggunaan yang meluas dari tim sehingga dapat menciptakan potensi untuk suatu organisasi membangkitkan kerja sama untuk melaksanakan tugas dan tanggung jawab sebagai pengelola pendidikan dan menjalankan fungsi perencanaan, pengorganisasian, dan pengawasan, untuk itu perlu diciptakan suatu tim kerja yang solid dalam mencapai tujuan dimana karakter tim selalu berbeda diperlukan kerja sama yang bersinergi positif.

Berdasarkan kerangka teoritik di atas, maka dapat diduga terdapat pengaruh langsung positif karakteristik tim terhadap kinerja Ketua Program Studi.

\section{Pengetahuan Manajemen dan Kinerja}

Pengetahuan manajemen adalah segala sesuatu yang diketahui seseorang berkaitan dengan fakta, istiah, konsep tentang fungsi manajemen dengan menggunakan komponen pengetahuan tentang konsep perencanaan (planning), pengetahuan tentang konsep pengorganisasian (organizing), pengetahuan tentang memimpin (leading), dan pengetahuan tentang pengendalian (controlling). Sedangkan proses manajemen diawali oleh fungsi merencanakan yang salah satu kegiatannya adalah merumuskan tujuan dan sasaran, kemudian dilanjutkan dengan fungsi pengorganisasian 
untuk menetapkan bagaimana mencapai tujuan dan siapa yang melaksanakannya.

Langkah berikutnya adalah pemimpin yang bertujuan menciptakan kondisi yang harmonis di antara sumber daya yang ada khususnya sumber daya manusia agar mereka dapat melaksanakan tugas-tugasnya dengan baik, sehingga tujuan organisasi dapat tercapai secara efisien dan efektif. Langkah terakhir adalah pengawasan untuk menentukan apakah tujuan yang sudah ditetapkan dapat tercapai atau tidak, sehingga dapat diketahui kelemahan-kelemahan yangdilakukan pada fungsi-fungsi sebelumnya, sehingga dapat dilakukan perbaikan untuk proses manajemen berikutnya. Jadi pengetahuan manajemen adalah merupakan apa yang diketahui seseorangyang dibangun secara terstruktur tentang suatu pengelolaan yang baik yang berupa proses perencanaan, pengorganisasian, kepemimpinan dan pengendalian. Terstruktur berarti pengetahuan yang dibangun melalui pengalaman langsung maupun hasil penelitian yang dapat membentuk konsep diri. Dan pengetahuan tersebut dapat memberikan petunjuk pada seseorang dalam melakukan aktivitas dalam menghadapi permasalahan sekarang maupun masa depan.

Secara rinci dapat disintesiskan bahwa kinerja ketua program studi dapat dilihat dalam melaksanakan tugas pokok dan fungsinya secara efektif dan efisien yang meliputi: (1) antar pribadi yang meliputi kegiatan simbolis, memimpin dan menghubungkan dengan pihak luar, (2) antar informasi meliputi kegiatan memantau menyebarkan, dan menjadi buru bicara, (3) pengambilan keputusan yang terdiri dari kewirausahaan, pengendalian dan gangguan pengalokasikan suber daya dan daya perunding.

Pencapaian kinerja pejabat tentang pengetahuan manajemen dapat memberikan pemahanan yang cukup berarti dalam pembentukan kinerja seseorang. Dengan adanya standar penilaan kinerja yang jelas maka ketua program studi akan dapat melakukan perjaannya dengan jelas pula, sesuai dengan ketentuan dan aturan yang berlaku. Berdasarkan kerangka teoritik di atas, maka dapat diduga terdapat pengaruh langsung positif pengetahuan manajemen terhadap kinerja ketua program studi. 


\section{Etika Kerja dan Kinerja.}

Etika kerja adalah nilai dan norma moral yang diterapkan oleh seseorang dan menjadi acuan dan pedoman dalam menjalankan tugas dengan melaksanakan pekerjaan dengan memilki prinsip efisien, rajin, teratur, disiplin, hemat, jujur dan teliti, rasional mengambil keputusan, bersedia menerima perubahan (terbuka), gesit memanfaatkan peluang (loyalitas), energik, ketulusan dan percaya diri, bekerja sama,mempunyai visi.Seorang yang memiliki etika kerja ditandai dengan rasa senang terhadap organisasi, tanda ini sekaligus kebanggaan, tingkat kehadirannya tinggi, sangat menikmati kerja, dan menempatkan pekerjaan sebagai citra dirinya.

Etika kerja ditandai dengan terbangunnya kepercayaan sesuai dengan prinsip-prinsip dalam pemberian wewenang dalam suatu organisasi dapat mendorong anggota untuk mengembangkan ide-ide dengan cepat, berani mengambil resiko, dan melakukan inovasi, sehingga dapat meningkatkan kinerja organisasi.

Kinerja adalah unjuk kerja yang dicapai pimpinan dalam menjalankan tugasnya sesuai dengan standar dan kriteria yang ditetapkan untuk pekerjaan itu. Esensi etika kerja adalah moral dan perilaku seseorang pimpinan sesuai dengan nilai dan norma yang sesuai dengan aturan yang berlaku. Pimpinan yang mempunyai etika kerja yang tinggi dalam melaksanakan tugasnya akan memperlihatkan kinerja yang tinggi seperti prestasi melebihi standar, absensi yang rendah dan pengetahuan, dan pemahaman tentang manajemen yang selalu meningkat. Dimilikinya etika kerja seorang ketau program studi tidak terlepas dari rasa percaya dan adil akan baiknya perlakuan manajemen terhadap mereka, yaitu adanya pendekatan manajemen terhadap sumber daya manusia sebagai "asset berharga" dan bukan semata-mata sebagai "komoditas" yang dapat dieksploitasi sekehendak manajemen.

Berdasarkan alur pemikiran yang demikian dapat diduga terdapat pengaruh langsung positif etika kerja terhadap kinerja ketua program studi.

\section{Karakteristik Tim dan Etika Kerja.}

Karakteristik tim adalah penilaian ketua program studi terhadap ciri spesifik suatu tim kerja yang ada di program studi untuk mendukung pencapaian tujuan program studi dengan melaksanakan komponen- 
komponen tertentu yaitu interaksi, struktur pekerjaan, peran teknis anggota, sasaran bersama, tanggungjawab, sharing nilai kultur, memiliki nilai budaya yang ada (spesifik), dan sinergi antar anggota.

Dengan demikian karakteristik tim akan mempengaruhi perilaku seseorang dalam melakukan sesuatu, mempertahankan kegiatan ke arah tercapainya tujuan yang telah ditentukan. Sejalan dengan itu, maka seorang pekerja memiliki karakteristik tim yang solid akan memperlihatkan prestasinya, meminta pengakuan atas apa yang diperolehnya, dan mempunyai etika kerja.

Seseorang yang memiliki karakteristik tim ditandai dengan kerja sama dan interaksi yang baik antara satu dengan lain dalam sebuah tim, terutama saling memberikan kesempatan untuk memberikan masukan tentang pengetahuan dan keterampilan dan saling mengisi antara satu dengan yang lain sebagai tanggung jawab untuk mencapai dan mengatasi berbagai rintangan.

Seorang yang memiliki etika kerja ditandai dengan rasa senang terhadap organisasi tanda ini sekaligus kebanggaan, tingkat kehadirannya tinggi, sangat menikmati kerja, dan menempatkan pekerjaan sebagai citra dirinya. Pengaruhnya, dengan karakteristik tim akan menumbuhkan konsep diri, yaitu kerja sama yang bersinergi positif, menikmati kerja, sukarela menerima tugas dan tanggung jawab, den bersedia mengahapi resiko. Bila berhasil melakukan kerja, secara instrinsik akan merasa senang dengan hasil yang dicapainya dan akan memiliki karakteristik tim yang bersinergi positif terhadap organisasinya, sehingga ia akan loyal, tidak mangkir, dan tidak terlambat melaksanakan tugasnya, berusaha bertahap dan tetap dalam organisasinya. Jika hal ini diterapkan kepada perilaku ketua program studi dalam bekerja, maka diharapkan etika kerja yang tinggi dalam bekerja dengan memperhatikan unsur-unsur yang mempengaruhi karakteristiknya. Sesuai dengan kerangka pemikiran ini, maka dapat diduga terdapat pengaruh langsung positif karakteristik tim terhadap etika ketua program studi.

\section{Pengetahuan Manajemen dan Etika Kerja}

Pengetahuan manajemen adalah segala sesuatu yang diketahui seseorang berkaitan dengan fakta, istiah, konsep tentang fungsi manajemen 
dengan menggunakan komponen pengetahuan tentang konsep perencanaan (planning), pengetahuan tentang konsep pengorganisasian (organizing), pengetahuan tentang memimpin (leading), dan pengetahuan tentang pengendalian (controlling). Sebagai perilaku kognitif tingkat awal yang menekankan pada proses mengingat, pengetahuan dapat berupa simbolsimbol verbal, atribut, sifat, hubungan, dan fakta yang dapat diingat dan dikenal kembali. Sementara Bloom kemudian membagi pengetahuan menjadi tingkatan besar, yaitu: (a) pengetahuan akan hal-hal yang khusus, (b) pengetahuan akan cara dan alat untuk berhubungan dengan hal yang khusus, dan (c) pengetahuan akan hal-hal yang umum dan abstrak dalam bidang tertentu. Sedangkan proses manajemen diawali oleh fungsi merencanakan yang salah satu kegiatannya adalah merumuskan tujuan dan sasaran, kemudian dilanjutkan dengan fungsi pengorganisasian untuk menetapkan bagaimana mencapai tujuan dan siapa yang melaksanakannya. Langkah berikutnya adalah pemimpin yang bertujuan menciptakan kondisi yang harmonis diantara sumber daya yang ada khususnya sumber daya manusia agar mereka dapat melaksanakan tugas-tugasnya dengan baik, sehingga tujuan organisasi dapat tercapai secara efisien dan efektif.

Langkah terakhir adalah pengawasan untuk menentukan apakah tujuan yang sudah ditetapkan dapat tercapai atau tidak, sehingga dapat diketahui kelemahan-kelemahan yang dilakukan pada fungsi-fungsi sebelumnya, sehingga dapat dilakukan perbaikan untuk proses manajemen berikutnya. Jadi pengetahuan manajemen adalah merupakan apa yang diketahui seseorang yang dibangun secara terstruktur tentang suatu konsep pengelolaan yang baik yang berupa proses perencanaan, pengorganisasian, kepemimpinan, dan pengendalian. Terstruktur berarti pengetahuan yang dibangun melalui pengalaman langsung maupun hasil penelitian yang dapat membentuk konsep diri. Pengetahuan tersebut dapat memberikan petunjuk pada seseorang dalam melakukan aktivitas dalam menghadapi permasalahan sekarang maupun masa depan. Seseorang yang memiliki etika kerjadi tandai dengan rasa senang terhadap organisasi. tanda ini sekaligus kebanggaan, tingkat kehadirannya tinggi, sangat menikmati kerja, dan menempatkan pekerjaan sebagai citra dirinya. Dengan adanya etika kerja maka ketua program studi akan dapat melaksanakan tugasnya sesuai 
dengan norma dan aturan yang berlaku, menikmati dan menempatkan pekerjaan sebagai citra dirinya, serta rasa tanggung jawab yang tinggi penuh rasa wibawa.

Dengan demikian maka dapat diduga terdapat pengaruh langsung positif pengetahuan manajemen terhadap etika kerja ketua program studi. Berdasar tinjauan teoritis di atas dan sesuai dengan permasalahan yang disusun, maka dapat dikemukakan hipotesis penelitian sebagai berikut; 1) Terdapat pengaruh langsung positif karakteristik tim terhadap kinerja ketua program studi, dan 2) Terdapat pengaruh langsung positif pengetahuan manajemen terhadap kinerja ketua program studi.

\section{METODOLOGI}

Penelitian ini menganalisis kinerja pimpinan ditinjau dari karakteristik tim, pengetahuan manajemen, dan etika kerja. Jadi dalam penelitian ini akan dibahas hubungan secara kausal antara keempat variabel. Secara umum penelitian ini terdapat pengaruh langsung positif etika kerja terhadap kinerja ketua program studi. Terdapat pengaruh langsung positif karaktersitik tim terhadap etika kerja. Terdapat pengaruh langsung positif pengetahuan manajemen terhadap etika kerja.

Berdasarkan deskripsi konseptual dan kerangka teoritik di atas, maka model teoritis yang diajukan digambarkan untuk mengetahui pengaruh antara variabel karakteristik tim, pengetahuan manajemen, dan etika kerja terhadap kinerja ketua program studi.

Secara khusus tujuan penelitian ini adalah untuk mengetahui: (1) Pengaruh langsung karakteristik tim terhadap kinerja, (2) Pengaruh langsung pengetahuan manajemen terhadap kinerja, (3) Pengaruh langsung etika kerja terhadap kinerja, (4) Pengaruh langsung karakteristik tim terhadap etika kerja, dan (5) Pengaruh langsung pengetahuan manajemen terhadap etika kerja.

Sesuai dengan tujuan penelitian maka metode yang digunakan adalah metode survei dengan teknik analisis jalur/path analisis yang akan menguji pengaruh langsung dan tidak langsung dari setiap variabel. Penelitian ini akan mengkaji atau menganalisis keterkaitan antar variabel penelitian, serta mengukur pengaruh satu variabel terhadap variabel lainnya. Variabel yang 
dikaji terdiri dari empat, yaitu: karakteristik tim $\left(\mathrm{X}_{1}\right)$, pengetahuan manajemen $\left(X_{2}\right)$, etika kerja $\left(X_{1}\right)$, dan kinerja pimpinan $\left(X_{2}\right)$.

Populasi dalam penelitian ini adalah seluruh ketua program studi di lingkungan Sekolah Tinggi Islam Swasta seKopertais Wilayah XIII Jambi berjumlah 92 program studi yang tersebar di 15 Sekolah Tinggi Islam Swasta. Penentuan besaran sampel menggunakan formula Slovin. Hasil perhitungan diperoleh besaran sampel sebesar 75 orang. Teknik pengambilan sampel dilakukan dengan menggunakan pendekatan acak sederhana.

Kerangka sampel (sample frame) adalah 75 orang ketua program studi di Sekolah Tinggi Islam swasta di Propinsi Jambi. Pemilihan dilakukan terhadap sekolah tinggi Islam dan tidak termasuk universitas maupun institut yang tersebar di Propinsi Jambi, dengan alasan karena Sekolah Tinggi Agama Islam tidak mempunyai fakultas dan memiliki disiplin keilmuan yang khusus dari Universitas Islam dan Institut Agama Islam. Sekolah Tinggi Agama Islam Swasta yang dipilih memiliki minimal empat jurusan dan delapan program studi agar homogenitas dari sampel dapat dipenuhi. Sampel yang dipilah secara acak berasal dari semua program studi yang terpilih tanpa membedakan tingkat pendidikan dan jenis kelamin ketua program studi. Dari deskripsi sampel tersebut terdapat 3 orang ketua program studi wanita dari 75 ketua program studi; terdapat 30 orang yang bekerja paruh waktu yang merupakan ketua program studi yang memiliki pekerjaan ganda sebagai pegawai negeri sipil, dan sisanya 42 orang sebagai ketua program studi yang penuh waktu.

Instrumen penelitian terdiri dari 4 (empat) buah, yakni, karakteristik tim, pengetahuan manajemen, etika kerja, dan kinerja ketua program studi. Sebelum digunakan sebagai alat penjaring data, instrumen tersebut diuji lebih dahulu kualitasnya. Kualitas instrument ditentukan oleh validitas (kehandalan) dan reliabilitas (keterpercayaan). Oleh sebab itu, setelah penyusunan instrumen dilanjutkan dengan uji coba instrumen yang melibatkan sampel 30 responden. Dalam hal pengujian validitas instrumen karakteristik tim, etika kerja, dan kinerja. Data yang diperoleh melalui penjaringan dengan menggunakan instrument tersebut diuji dengan menggunakan formula product moment, mengkorelasikan antara skor butir 
dan skor totalnya. Koefisien rhitung (koefisien relasi) tersebut dibandingkan dengan $r$ tabel $d f=n-2$ dan taraf signifikansi $a=0,36$. Untuk menguji validitas instrument variable pengetahuan manajemen menggunakan formula korelasi point biserial. Sedangkan untuk menguji reliabilitas instrument karakteristik tim, etika kerja, dan kinerja digunakan formula Alfha Cronbach. Untuk menguji reliabilitas instrument pengetahuan manajemen menggunakan formula Khuder Ricardson (KR 20). Secara keseluruhan proses perhitungan dengan menggunakan excel. Rincian pengembangan instrument untuk masing-masing variabel dijelaskan berikut Ini :

Kinerja adalah unjuk kerja pimpinan dalam menjalankan tugasnya sesuai dengan standar dan kriteria yang ditetapkan untuk pekerjaan itu dengan indikator ; (1) menyusun program kerja, (2) menetapkan tujuan kerja, (3) melaksanakan efesiensi kerja, dan (4) memberdayakan bawahan.

Kinerja adalah unjuk kerja yang dilaksanakan oleh ketua program studi untuk mencapai tujuan yang telah ditentukan sesuai dengan standar dan kriteria yang ditetapkan untuk pekerjaan itu yang dinilai oleh tiga orang dalam bentuk skor yang diperoleh dari hasil pengisian instrumen yang diuraikan dari indikator; (1) menyusun program kerja, (2) menetapkan tujuan kerja, (3) melaksanakan efesiensi kerja, dan (4) memberdayakan bawahan.

Berdasarkan perhitungan uji validitas butir yang menggunakan teknik korelasi product moment dengan 0,36 dari 30 butir diperoleh butir 10 dan 26 yang tidak valid (drop), sehingga variabel kinerja ketua program studi masih memiliki 28 butir yang valid yang dipergunakan untuk mengambil data.

Hasil perhitungan reliabilitas terhadap 28 butir instrumen, diperoleh koefisien sebesar 0,92. Dengan demikian ke -28 butir instrumen tersebut dapat digunakan dalam penjaringan data dalam penelitian.

Karakteristik tim adalah penilaian ketua program studi terhadap ciri spesifik suatu tim kerja yang ada di program studi untuk mendukung pencapaian tujuan program studi dengan indikator: (1) interaksi, (2) struktur pekerjaan, (3) peran teknis anggota, (4) sasaran bersama, (5) tanggung jawab, (6) nilai kultur, (7) memiliki nilai budaya yang ada (spesifik), dan (8) sinergi antar anggota.

Karakteristik tim adalah ciri spesifik suatu tim kerja yang ada di program studi untuk mendukung pencapaian tujuan program studi dengan 
indikator: (1) interaksi, (2) struktur pekerjaan, (3) peran teknis anggota, (4) sasaran bersama, (5) tanggung jawab, (6) nilai kultur, (7) memiliki nilai budaya yang ada (spesifik), dan (8) sinergi antar anggota.

Berdasarkan perhitungan uji validitas butir yang menggunakan teknik korelasi dengan rumus dari 31 butir diperoleh butir 7 dan 23 yang tidak valid (drop), sehingga variabel karakteristik tim masih memiliki 29 butir yang valid yang dipergunakan untuk mengambil data. Hasil perhitungan reliabilitas terhadap 29 butir instrumen, diperoleh koefisien sebesar 0,91. Dengan demikian ke 29 butir instrumen tersebut dapat digunakan dalam penjaringan data dalam penelitian.

Pengetahuan manajemen adalah segala sesuatu yang diketahui seseorang berkaitan dengan fakta, istiah, dan konsep tentang fungsi manajemen dengan indikator-indikator: (1) pengetahuan tentang konsep perencanaan (planning), (2) pengetahuan tentang konsep pengorganisasian (organizing), (3) pengetahuan tentang memimpin (leading), dan (4) pengetahuan tentang pengendalian (controlling).

Pengetahuan manajemen adalah segala sesuatu yang diketahui ketua program studi berkaitan dengan fakta, istiah, konsep tentang fungsi manajemen dengan indikator-indikator: (1) pengetahuan tentang konsep perencanaan (planning), (2) pengetahuan tentang konsep pengorganisasian (organizing), (3) pengetahuan tentang memimpin (leading), (4) pengetahuan tentang pengendalian (controlling) yang diukur dengan tes.

Berdasarkan perhitungan uji validitas butir yang menggunakan teknik korelasi dengan rhwo 36 diperoleh butir 3, 14, 25, dan 32 yang tidak valid (drop), sehingga variabel pengetahuan manajemen masih memiliki 40 butir yang valid. Ke-40 butir tersebut dihitung koefisien realibilitas instrumennya dengan menggunakan formula Khuder Richardson 20. Hasil perhitungan diperoleh koefisien reliabilitas sebesar 0,95. Dengan demikian ke-40 butir tersebut dapat dijadikan sebagai alat pengumpul data penelitian.

Etika kerja adalah nilai dan norma moral yang diterapkan oleh seseorang dan menjadi acuan dan pedoman dalam menjalankan tugas dengan indikator: (1) efisien, (2) rajin, (3) teratur, (4) disiplin, (5) hemat, (6) Jujur dan teliti, (7) rasional mengambil keputusan, (8) bersedia menerima perubahan (terbuka), (9), gesit memanfaatkan peluang (loyalitas), dan (10) 
energik, (11) ketulusan dan percaya diri, (12) bekerja sama, (13) dan mempunyai visi.

Etika kerja adalah nilai dan norma moral yang diterapkan ketua program studi dalam bekerja melaksanakan tugas sebagai ketua program studi dengan indikator: (1) efisien, (2) rajin, (3) teratur, (4) disiplin, (5) hemat, (6) jujur dan teliti, (7) rasional mengambil keputusan, (8) bersedia menerima perubahan (terbuka), (9). gesit memanfaatkan peluang (loyalitas), (10) energik, (11) ketulusan dan percaya diri, (12) bekerja sama, dan (13) mempunyai visi.

Berdasarkan perhitungan uji validitas butir yang menggunakan teknik korelasi product moment dengan rm 0,36 dari 30 butir diperoleh butir 12 yang tidak valid, sehingga variabel karakteristik tim masih memiliki 29 butir valid yang dipergunakan untuk mengambil data. Hasil perhitungan reliabilitas terhadap 29 butir instrumen, diperoleh koefisien sebesar 0,72. Dengan demikian ke-29 butir instrumen tersebut dapat digunakan dalam penjaringan data penelitian.

\section{HASIL PENELITIAN}

Data yang dikumpulkan dalam penelitian ini meliputi data karakteristik tim $\left(X_{1}\right)$, pengetahuan manajemen $\left(X_{2}\right)$, etika Kerja $\left(X_{3}\right)$, dan kinerja $\left(X_{4}\right)$. Hasil penjaringan data melalui instrumen penelitian menunjukan hal-hal sebagaimana di sampaikan pada table 4.1 di bawah ini.

\section{Tabel 1}

Skor Instrumen

\begin{tabular}{|c|c|c|c|c|c|}
\hline $\begin{array}{c}\text { Instrumen } \\
\text { Varibel }\end{array}$ & $\sum$ Butir & \multicolumn{2}{|c|}{ Skor Teoritik } & \multicolumn{2}{|c|}{$\begin{array}{c}\text { Skor Hasil } \\
\text { Penelitian }\end{array}$} \\
\cline { 2 - 6 } & Terendah & Tertinggi & Terendah & Tertinggi \\
\hline $\begin{array}{c}\text { Karakteristik Tim } \\
\left(X_{1}\right)\end{array}$ & 28 & 28 & 140 & 79 & 128 \\
\hline $\begin{array}{c}\text { Pengetahuan } \\
\text { Manajemen }\left(X_{2}\right)\end{array}$ & 40 & 0 & 40 & 14 & 39 \\
\hline Etika Kerja $\left(X_{3}\right)$ & 29 & 29 & 145 & 104 & 120 \\
\hline Kinerja $\left(X_{4}\right)$ & 30 & 30 & 150 & 99 & 115 \\
\hline
\end{tabular}


Secara lengkap deskripsi statistic masing-masing variabel seperti yang disajikan pada tabel 1 di atas dijelaskansebagai berikut:

a. Instrumen karakteristik tim terdiri dari 28 item pernyataan, sehingga secara teoritik rentang skor yang diperoleh dari anggota sample adalah $28-140$. Hasil pengumpulan data menunjukan skor terendah 79 dan tertinggi 128.

b. Instrumen pengetahuan manajemen terdiri dari 40 item pernyataan, sehingga secara teoritik rentang skor yang diperoleh dari anggota sampel adalah 0-40. Hasil pengumpulan data menunjukkan skor terendah 14 dan tertinggi 39.

c. Instrumen etika kerja terdiri dari 29 item pernyataan, sehingga secara teoritik rentang skor yang diperoleh dari anggota sampel adalah 29145. Hasil pengumpulan data menunjukan skor terendah 104 dan tertinggi 120.

d. Instrumen kinerja terdiri dari 30 item pernyataan, sehingga secara teoritik rentang skor yang diperoleh dari anggota sampel adalah 30150. Hasil pengumpulan data menunjukan skor terendah 99 dan tertinggi 115.

e. Hasil pengujian regresi $X_{3}=94.75+0.68 X_{2}$ Data berdistribusi Normal.

Pengujian persyaratan analisis di maksud adalah uji linieritas regresi, normalitas Galat taksiran untuk setiap persamaan regresi.

\section{Pengujian Normalitas Galat Taksiran}

1) Hasil pengujian regresi $X_{4}=71.96+0.33 X_{1}$ Data berdistribusi Normal

2) Hasil pengujian regresi $X_{4}=85.18+0.84 X_{2}$ Data berdistribusi Normal

3) Hasil pengujian regresi $X_{4}=69.42+0.34 X_{3}$ Data berdistribusi Normal

4) Hasil pengujian regresi $X_{3}=77.64+0.33 X_{1}$ Data berdistribusi Normal

5) Hasil pengujian regresi $X_{3}=94.75+0.68 X_{2}$ Data berdistribusi Normal 


\section{Uji Linieritas Regresi}

1) Regresi $x_{4}$ atas $x_{1}$ adalah: $x_{4}=71.96+0.33 x_{1}$ hasil perhtungan bersifat linier

2) Regresi $x_{4}$ atas $x_{2}$ adalah: $x_{2}=85.18+0.84 x_{1}$ hasil perhitungan bersifat linier.

3) Regresi $x_{4}$ atas $x_{3}$ adalah: $x_{4}=69.42+0.34 x_{3}$ hasl perhitungan bersifat linier.

4) Regresi $x_{3}$ atas $x_{1}$ adalah: $x_{3}=77.64+0.33 x_{1}$ hasil perhitungan bersifat linier.

5) Regresi $x_{3}$ atas $x_{2}$ adalah: $x_{3}=94.75+0.86 x_{2}$ hasil perhitungan bersifat linier.

\section{Pengujian Hipotesis}

Hasil pengujian model diproleh koefisien jalur seperti yang terdapat pada gambar di bawah ini :

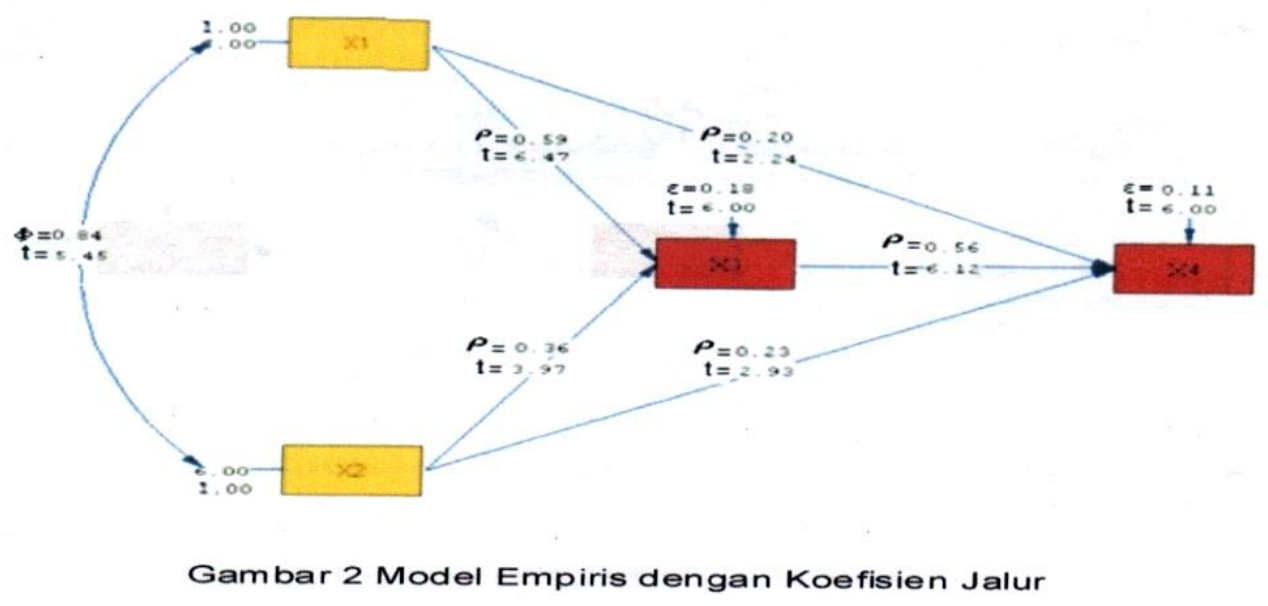

Untuk melihat signifikansi model empiris dapat memanfaatkan skor $\mathrm{t}$ sebagaimana ditampilkan pada gambar di atas. Mengingat model di atas dibangun melalui dua persamaan struktural, maka selanjutnya dilakukan uji linieritas dengan menggunakan uji $\mathrm{F}$, setelah itu dilanjutkan dengan pengujian hipotesis. Hasil pengujian persamaan sturktural dijelaskan sebagai berikut:

\section{Pengujian Model Persamaan}

Struktural 1: $\mathrm{X}_{4}=\mathrm{P}_{41} \mathrm{X}_{1}+{ }_{4} \mathrm{P}_{2} \mathrm{X}_{2}+\mathrm{P}_{43} \mathrm{X}_{3}$ Hasil pengujian: $\mathrm{X}_{4}=0.56 \mathrm{X}_{3}+$ $0.20 X_{1},+0.23 X_{2}$. 
Persamaan di atas kemudian diuji linieritasnya dengan menggunakan formula F. Berdasarkan perhitungan diperoleh nilai $F_{\text {hitung }}$ sebesar 109. 33. Kriteria penolakan $\mathrm{H} €: \mathrm{F}_{\text {hitung }}>\mathrm{F}_{\text {tabel }}$ atau $\mathrm{F} €>\mathrm{Fa} 1 \mathrm{n}-3$, dengan mengambil taraf signifikansi $\alpha=0,05$, maka dari tabel distribusi $F$ diperoleh nilai Ftabel

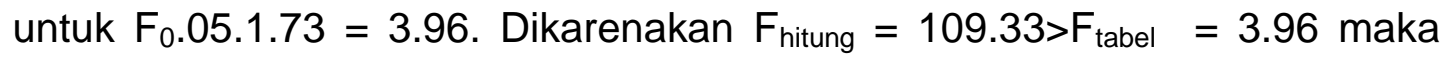
dapat disimpulkan bahwa model persamaan struktural satu linier. Diperoleh pula skor determinasi (kontribusi) sebesar $R_{2}=0.89$ dan error variance (kesalahan pengukuran) $€=0.11$. Skor kontribusi $R_{2}=0.89$ menyatakan bahwa variabilitas kinerja dapat dijelaskan oleh karakteristik tim, pengetahuan manajemen, dan etika kerja sebesar $89 \%$, sisanya dapat dijelaskan oleh variabel lain. Selengkapnya model pengaruh sebagaimana hasil perhitungan tersebut dapat divisualisasikan pada gambar berikut:

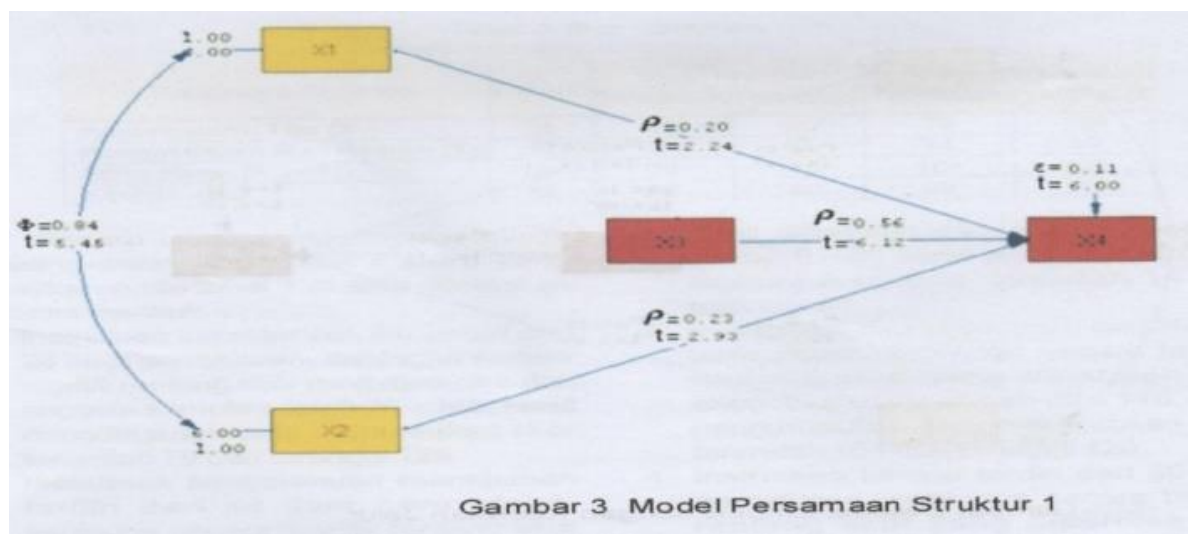

Gambar 3 Model Persamaan Struktur 1

Berdasarkan persamaan satu di atas, dilanjutkan dengan pengujian hipotesis sebagai berikut:

Uji Hipotesis 1: Pengaruh Langsung Positif Karakteristik Tim terhadap kinerja.

Hasil perhitungan menunjukan koefisien jalur karakteristik tim terhadap kinerja ketua program studi sebesar P41 $=0.20$, berarti terdapat pengaruh langsung positif karakteristik tim terhadap kinerja ketua program studi sebesar. Koefisien jalur $\mathrm{P}_{41}=0.20$ menolak $\mathrm{H}_{0}$ karena $t_{\text {hitung }}=2.24>_{\text {tabel }}=1.98$, sehingga jalur $P_{41}$ signifikan.

Uji Hipotesis 2: Pengaruh Langsung Positif Pengetahuan Manajemen terhadap Kinerja. 
Hasil perhitungan menunjukkan koefisien jalur $\mathrm{X}_{2}$ ke $\mathrm{X}_{4}$ adalah $\mathrm{P}_{42}=$ 0,23 , menolak $\mathrm{H}_{\mathrm{o}}$ karena $\mathrm{t}_{\text {hitung }}=2.93>\mathrm{t}_{\text {tabel }}=1.98$ sehingga jalur berarti terdapat pengaruh langsung positif pengetahuan manajemen terhadap kinerja ketua program studi. Koefisien jalur $P_{42}=0,23$ menolak Ho karena $t_{\text {hitung }}=2,93>t_{\text {tabel }}=1,98$ sehingga jalur $P_{42}$ signifikan.

Uji Hipotesis 3: Pengaruh LangsungPositif Etika Kerja terhadap Kinerja Ketua Program Studi.

Hasil perhitungan menunjukan koefisien jalur $X_{3}$ ke $X$ adalah $P_{3}=$ 0,56, berarti terdapat pengaruh langsung positif etika kerja terhadap kinerja ketua program studi. Koefisien jalur $\mathrm{P}_{43}$ : 0,56 menolak $\mathrm{H}_{\mathrm{O}}$ karena thihmg $=6,12>\operatorname{tmt}=1,98$ sehingga jalur [343 signifikan .

Pengujian Model Persamaan Struktural 2: $\mathrm{X}_{3}=\mathrm{P}_{31} \mathrm{X} 1+\mathrm{P}_{32} \mathrm{X}_{1}$ Hasil pengujian menghasilkan: $X_{3}=0 n g 1+0.36 X_{2} \_$Skor thitung diperoleh masingmasing $\mathrm{X} 1=6.47, \mathrm{X} 2=3.97$ semuanya signifikan pada $0=0.05$ dengan tlab $=1,98$. Persamaan di atas kemudian diuji linieritasnya dengan menggunakan formula F. Berdasarkan perhitungan sebagaimana pada lampiran diperoleh FMU sebesar 166.28. Kriteria penolakan $H_{0}$ dan $t_{\text {hitung }}>F_{\text {tabel }}$ atau Fo $>$ $\mathrm{Fa}=0,0512$ dengan mengambil taraf signifikansi (u) sebesar 5\% maka dari table distribusi $F$ diperoleh nilai $F_{\text {tabel }}$ untuk Facsm $=3.96$. Dikarenakan Fm = $166.28>\mathrm{Fla}=3.96$ maka $\mathrm{H}_{\mathrm{o}}$ ditolak. Artinya dapat disimpulkan bahwa model persamaan struktural satu linier. Diperoleh pula skor determinasi (kontribusi) sebesar $R_{2}=0.82$ dan error variance (kesalahan pengukuran) $=0.18$. Skor kontribusi $\mathrm{R} 2=0.82$ menyatakan bahwa variabilitas etika kerja dapat dijelaskan oleh karakteristik tim dan pengetahuan manajemen sebesar $82 \%$, sisanya dapat dijelaskan oleh variabel lain. Hasil perhitungan juga menunjukkan korelasi antara karakteristik tim dan pengetahuan manajemen memiliki korelasi $r=0,84$ yang menunjukkan bahwa terdapat hubungan positif antara karakteristik tim dengan pengetahuan manajemen. Skor thitung sebesar 5,45 menunjukan hubungan antara dua variabel tersebut signifikan. Selengkapnya model pengaruh sebagaimana hasil perhitungan tersebut dapat divisualisasikan pada gambar berikut: 


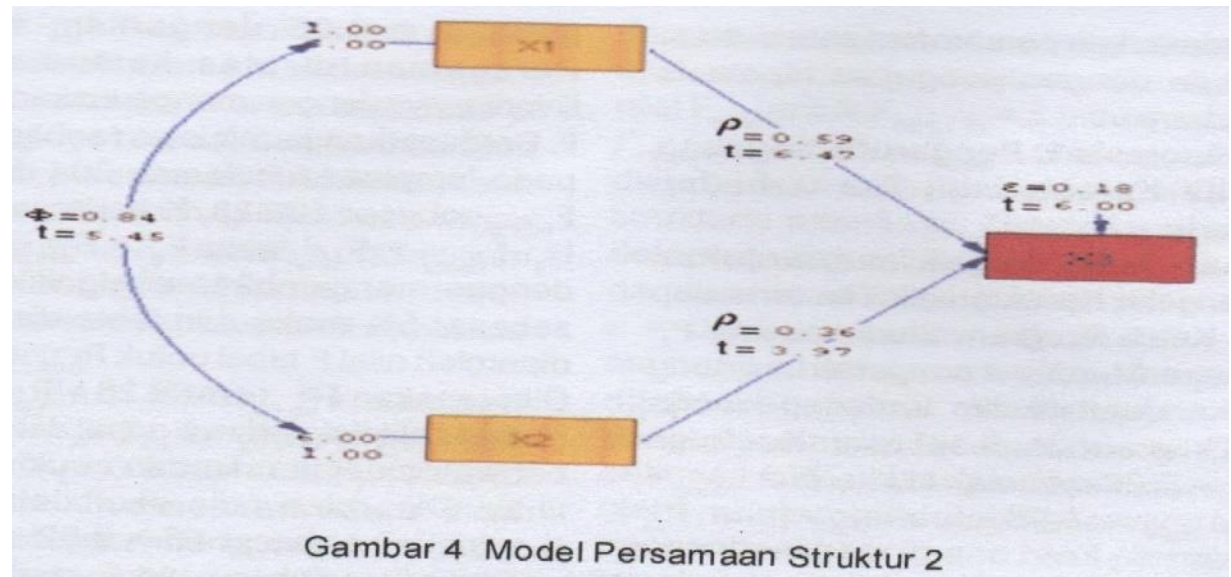

Berdasarkan persamaan dua di data dilanjutkan dengan pengujian hipotesis sebagai berikut:

1) Uji Hipotesis 4: Pengaruh Langsung Karakteristik Tim terhadap Etika Kerja Hasil perhitungan menunjukkan koefisien jalur $\mathrm{X}_{1}$ ke $\mathrm{X}_{3}$ adalah $\mathrm{P}_{41}=0.59$ yang berarti terdapat pengaruh langsung karakteristik tim terhadap etika kerja. Koefisien jalur $\mathrm{PH}=0.59$ menolak Ha karena tmn, $=6,47>$ taw $-1,98$ atau $t^{\circ}>$ ta $1, n-3(a=0.05)$. sehingga jalur $\mathrm{Ba}$, signifikan.

2) Uji Hipotesis 5: Pengaruh LangsungPengetahuan Manajemen terhadap Etika Kerja Berdasarkan persamaan dua, koefisien jalur $\mathrm{X}_{2}$ ke $X_{3}$ adalah sebesar $P_{32}=0.36$ yang berarti pengaruh langsung pengetahuan manajemen terhadap etika sebesar 0,36. Koefisien jalur $P_{32}=0.36$ tersebut menolak Ho karena thitung $=3,97>t_{\text {label }}=1,98$ atau $t^{\circ}>$ ta $1, n \_3(\$ 005)$, dengan demikian maka jalur $P_{3}$ dinyatakan signifikan.

\section{PEMBAHASAN}

Para ahli teori perilaku organisasi menyebutkan bahwa kinerja pimpinan organisasi dipengaruhi oleh berbagai faktor. Colquit (2009), mengemukakan ada 19 faktor yang mempengaruhi kinerja, diantaranya karakteristik tim, kepemimpinan, dan etika kerja yang menjadi topik penelitian ini.

Kinerja yang baik dalam organisasi terbangun dari tim yang berkinerja tinggi dimana ia memiliki beberapa karakteristik, sebagaimana diungkapkan oleh Stephen P. Robbins (2007: 39) secara umum tim berkinerja tinggi memiliki beberapa karakteristik, yaitu: tujuan akhir yang jelas dan bernilai, 
pelaksanaan tugas (task driven) struktur berorientasi hasil, kemampuan, dan kecakapan anggota kelompok dalam bekerja keras, iklim kolaboratif, standar tinggi keberhasilan, pengakuan dan dukungan pihak luar, pengarahan kuat, dan berprinsip. Oleh sebab itu karakteristik tim dapat berpengaruh langsung maupun tidak langsung terhadap kinerja.

Kinerja dipengaruhi oleh pengetahuan manajemen seorang manajer. Robin dan Coulter (2005), menjelaskan bahwa pengetahuan manajemen dapat mempengaruhi kinerja. Sebab pada dasarnya pengetahuan manajemen menanamkan suatu budaya belajar, jika anggota organisasi yang secara sistematis mengumpulkan pengetahuan yang lain dalam organisasi agar suapaya mencapai kinerja yang lebih baik.

Pengetahuan manajemen meliputi fungsi-fungsi seperti yang diungkapkan oleh Robbins dan Coulter (1999: 39) yaitu; merencanakan (planning), mengorganisasikan (organizing), memimpin (leading), dan mengawasi (controlling). Pelaksanaan fungsi-fungsi manajemen ini manajer dapat menjalankan proses manajerialnya sehingga dapat mencapai kinerja yang tinggi dalam sebuah organisasi. Teori yang melandasi bahwa etika kerja dapat mempengaruhi kinerja adalah teori norma budaya dan moral. Roger B. Hill (1996), memberi definisi etika kerja sebagai berikut: "the work ethic is a cultural norm that advocates being personally accountable and responsible for the work that one does". Etika kerja adalah norma budaya yang menunjukkan bahwa orang beretika kerja dapat dipercaya dan bertanggung jawab terhadap pekerjaan yang dilakukan. Kementerian Pelajaran Malaysia (2003: 1) menyebutkan bahwa etika kerja adalah Panduan tingkah laku yang menjadi pegangan setiap warga kementerian pelajaran Malaysia berlandaskan nilai-nilai akhlak mulia.

Luthan (2009: 47) menjelaskan bahwa masalah-masalah moralitas yang mengelilingi etika di tempat kerja, ada fakta-fakta penting bahwa kodekode etika dan menjadi etis berdampak baik bagi organisasi. Himpunan fakta-fakta tentang nilai praktik-praktik etika menuntun pada pengembangan teori, penelitian, dan pengukuran tentang Kinerja Sosial Perusahaan (KSP) atau Corporate Social Performance (CSP).

Kinerja dalam sebuah organisasi tergantung dengan norma budaya dan moral pimpinan yang dapat memberikan contoh yang baik bagi anggota 
organisasi sehingga tugas yang dilaksanakan oleh anggota organisasi atau karyawan dapat mencapai kinerja sesuai dengan yang direncanakan dan sebaliknya. Dengan demikian maka kinerja pimpinan dipengaruhi oleh etika kerja.

Hasil penelitian ini menyatakan bahwa karakteristik tim, etika kerja, dan pengetahuan manajemen berpengaruh langsung terhadap kinerja berturut-turut sebesar $\mathrm{P}=0,20, \mathrm{Pu}=0,23, \mathrm{Pu}=0,564 \mathrm{Hal}$ ini dapat diinterpretasikan bahwa setiap kenaikan satu simpangan baku pada nilai karakteristik tim akan meningkatkan nilai kinerja sebesar 0,20 simpangan baku. Kemudian, setiap kenaikan satu simpangan baku pada nilai etika kerja akan meningkatkan nilai kinerja sebesar 0,56 simpangan baku. Demikian pula, setiap kenaikan satu simpangan baku pada pengetahuan manajemen akan meningkatkan nilai kinerja sebesar 0,23 simpangan baku. Determinan pengaruh karakteristik tim, pengetahuan manajemen, etika kerja terhadap kinerja sebesar $R_{2}=0,89$, menyatakan bahwa variabilitas kinerja dapat dijelaskan oleh karaktristik tim, dan etika kerja, dan pengetahuan manajemen sebesar $89 \%$, selebihnya dijelaskan oleh variabel lain. Oleh sebab itu jika hanya memilih tiga di antara banyak variabel yang mempengaruhi kinerja maka tingkat kesalahan pengukuranya terhadap kinerja sebesar 0,11 atau $11 \%$

Pengaruh etika kerja terhadap kinerja ditandai dengan terbangunnya kepercayaan sesuai dengan prinsip-prinsip dalam pemberian wewenang dalam suatu organisasi dapat mendorong anggota untuk mengembangkan ide-ide dengan cepat, berani mengambil resiko, dan melakukan inovasi, sehingga dapat meningkatkan kinerja organisasi. Sebagaimana yang dijelaskan oleh Bertens (1999 :222) bahwa etika kewajiban dan etika keutamaan muncul bersamaan dalam menuntun dan melandasi perilaku manusia. Nilai-nilai moral dalam etika kewajiban merupakan suatu imperatif kategoris, yang berarti bahwa nilai moral mewajibkan kita tanpa syarat untuk mewujudkan nilai moral tersebut. Yang termasuk sebagai nilai moral tersebut ialah: (1) kejujuran; (2) tanggung jawab; dan (3) kesetiaan. Etika keutamaan itu mempelajari sifat watak manusia yang memiliki empat pokok keutamaan ialah: (1) kebijaksanaan; (2) keberanian; (3) pengendalian diri; dan (4) keadilan. Gunnar Myrdal (1990: 90-91) mengemukakan tiga belas sikap yang 
memadai untuk etika kerja yang tinggi pada seseorang, yaitu: 1) efesien; 2) rajin; 3) teratur; 4) disiplin/tepat waktu; 5) hemat; 6) jujur dan teliti; 7) rasional dalam mengambil keputusan; 8) bersedia menerima perubahan; 9) gesit dalam memanfaatkan kesempatan; 10) energik; 11) ketulusan dan percaya diri; 12) mampu bekerja sama; 1dan 3) mempunyai visi yang jauh ke depan.

Hasil penelitian ini selanjutnya menyatakan bahwa karakteristik tim dan pengetahuan manajemen berpengaruh langsung terhadap etika kerja berturut-turut sebesar P3 $=0,59$, PS 2: 0,36. Hal ini dapat diinterpretasikan bahwa setiap kenaikan satu simpangan baku pada nilai karakteristik tim akan meningkatkan nilai etika kerja sebesar 0,59 simpangan baku.

Kemudian, setiap kenaikan satu simpangan baku pada pengetahuan manajemen akan meningkatkan nilai etika kerja sebesar 0,36 simpangan baku. Determinan pengaruh karakteristik tim, pengetahuan manajemen, dan etika kerja terhadap kinerja sebesar $\mathrm{R} 2=0,82$, menyatakan bahwa variabilitas etika kerja dapat dijelaskan oleh karaktristik tim dan pengetahuan manajemen sebesar $82 \%$, selebihnya dijelaskan oleh variabel lain. Pengharuh karakteristik tim terhadapetika kerja tercermin pada perilaku seseorang dalam melakukan sesuatu, mempertahankan kegiatan kearah tercapainya tujuan yang telah ditentukan Sejalan dengan pendapat yang dikemukakan oleh Konopaske dan Matteson (2006: 259-260) bahwa karakteristik tim memiliki pengaruh terhadap etika kerja dengan yang terdiri dari beberapa karakteristik. Pertama, dua atau lebih individu saling berinteraksi. Kedua, tim menyediakan struktur untuk pekerjaan dan interaksi di antara anggotanya. Ketiga, anggotanya dapat menampilkan peran teknis spesifik, kepemimpinan, penyelesaian masalah, dan sisi emosional. Keempat, tim memiliki sasaran bersama. Kelima, tim secara internal bertanggung jawab satu dengan yang lain dan keterampilan setiap anggota melengkapi kemampuan yang dimiliki anggota lainnya. Keenam, tim berbagi budaya, serangkaian ritual, dan proses, serta filosofi dalam bekerja bersama.

Teori di atas menunjukkan bahwa karakteristik tim sangat diperlukan guna menciptakan etika kerja dalam organisasi. Pendapat ini diperkuat oleh pendangan yang dikemukakan Stoner dalam Sindoro (1996: 505-506) menyebutkan bahwa perlunya pemantapan norma, di mana kesatuan 
kelompok muncul ketika anggota menetapkan sasaran umum, norma, dan peraturan dasar.

Mensikapi pandangan di atas, seorang manajer dituntut memiliki pengetahuan manajemen. Karena pada dasarnya pengetahuan manajemen menanamkan suatu budaya belajar. Sementara pengetahuan itu diperoleh manusia melalui proses belajar. Dengan demikian diduga pengetahuan manajemen dapat memberikan kontribusi yang cukup berarti atau semakin baik pengetahuan seseorang maka akan baik pula dalam membuat atau mempengaruhi etika kerja seseorang. Artinya pengetahuan manajemen dapat mempengaruhi etika kerja seseorang.

\section{Keterbatasan Peneliti}

Sebagai sebuah penelitian, telah dilakukan dengan sebaik mungkin sesuai dengan prosedur ilmiah, Namun didasari bahwa hasil yang diperoleh tidak luput dari kekurangan atau kelemahan akibat keterbatasan yang ada, sehingga menimbulkan hasil yang kurang sesuai dengan yang diharapkan. Keterbatasan yang mungkin terjadi selama berlangsungnya penelitian ini.

Pertama, karena penelitian ini hanya dilakukan terhadap ketua program studi pada Sekolah Tinggi Islam Swasta di Propinsi Jambi, sehingga penelitian ini hanya dapat digeneralisasikan terhadap populasi yang memiliki karakteristik yang sama dengan sampel penelitian.

Kedua, tidak ada kontrol terhadap variabel-variabel yang lain selain karakteristik tim, pengetahuan manajemen, dan etika kerja sehingga kemungkinan masih ada variabel lain yang dapat mempengaruhi variabel kinerja pimpinan.

\section{SIMPULAN}

Berdasarkan hasil analisis data dan perhitungan statistik sebagaimana yang diuraikan pada bab sebelumnya, maka temuan dari hasil penelitian ini dapat disimpulkan sebagai berikut; 1) Terdapat pengaruh langsung positif karakteristik tim terhadap kinerja. Artinya peningkatan kinerja harus diawali dengan penguatan karakteristik tim, 2) Terdapat pengaruh langsung posistif pengetahuan manajemen terhadap kinerja. Artinya peningkatan kinerja harus diawali dengan peningkatan pengetahuan manajemen, 3) Terdapat pengaruh 
langsung positif etika kerja terhadap kinerja. Artinya peningkatan kinerja harus diawali dengan peningkatan etika Kerja, 4) Terdapat pengaruh langsung positif karakteristik tim terhadap etika kerja. Artinya peningkatan etika kerja harus diawali dengan penguatan karakteristik tim, 5) Terdapat pengaruh langsung positif pengetahuan manajemen terhadap etika kerja, Artinya peningkatan etika kerja dilakukan terlebih dahulu peningkatan pengetahuan manajemen.

Dari dua variabel eksogenus, yaitu karakteristik tim dan pengetahuan manajemen dapat disimpulkan bahwa variabel pengetahuan manajemen adalah yang sangat berpengaruh terhadap etika kerja. Dapat pula dilihat bahwa dari ketiga variabel karakteristik tim, pengetahuan manajemen, dan etika kerja bahwa variabel karakteristik tim yang paling dominan berpengaruh terhadap kinerja ketua program studi kemudian disusul variabel etika kerja berpengaruh terhadap kinerja pimpinan. Sedangkan kinerja pimpinan hanya dipengaruhi oleh variabel pengetahuan manajemen.

Berdasarkan temuan tersebut dapat dikemukakan bahwa variasi kinerja ketua program studi dipengaruhi oleh berbagai variasi diantaranya variasi karakteristik tim, variabel pengetahuan manajemen, dan variasi etika kerja.

Berdasarkan kesimpulan yang telah dikemukakan di atas maka dirumuskan implikasi penelitian sebagai berikut; 1) Pengaruh langsung positif karakteristik tim terhadap kinerja bahwa untuk meningkatkan kinerja ketua program studi harus diawali dengan penguatan karakteristik tim. Dalam konteks ini penguatan karakteristik tim akan sangat menentukan bagi terciptanya kinerja yang tinggi bagi ketua program studi dalam melaksanakan tugas-tugas sebagai ketua program studi, 2) Pengaruh langsung positif pengetahuan manajemen terhadap kinerja. mengartikan bahwa untuk meningkatkan kinerja ketua program studi harus diawali dengan peningkatan pengetahuan manajemen yang memadai. Pengetahuan manajemen yang memadai bagi ketua program studi dapat membuat dan memiliki kinerja tinggi dalam menjalankan tugas-tugas sebagai ketua program studi, 3) Pengaruh langsung positif etika kerja terhadap kinerja. Etika kerja terhadap kinerja menyatakan bahwa dalam meningkatkan kinerja ketua program studi memerlukan peningkatan etika kerja ketua program studi. Terdapatnya etika 
kerja ketua program studi dalam melaksanakan tugas-tugasnya akan berdampak nyata pada peningkatan kinerja ketua program studi, 4) Pengaruh langsung positif karakteristik tim terhadap etlka kerja menyatakan bahwa dalam meningkatkan etika kerja ketua program studi membutuhkan peningkatan dan penguatan karakterisitik tim dalam program studi. Karakteristik tim yang terbangun dengan baik dan menguat akan berdampak pada peningkatan etika kerja ketua program studi, dan 5) Pengaruh langsung positif pengetahuan manajemen terhadap etika kerja menunjukkan bahwa dalam meningkatkan etika kerja harus diawali dengan peningkatan pengetahuan manajemen ketua program studi. Semakin baik dan memadai pengetahuan manajemen ketua program studi maka semakin memberi peluang bagi terbentuknya etika kerja ketua program studi itu sendiri.

Bertitik tolak pada implikasi di atas, maka dapat dirumuskan bahwa kinerja ketua program studi Sekolah Tinggi Islam Swasta di Propinsi Jambi dapat diciptakan melalui upaya-upaya dengan memberikan penguatan dan peningkatan karakteristik tim, meningkatkan pengetahuan manajemen, dan meningkatkan etika kerja ketua program studi itu sendiri. Semakin terbangun dan menguatnya karakteristik tim program studi kearah yang lebih baik dari sebelumnya, terdapatnya pengetahuan manajemen yang memadai, dan terbentuknya etika kerja ketua program studi diiringi oleh peningkatan kinerja ketua program studi di lingkungan program studi.

Etika kerja ketua program studi dapat ditingkatkan melalui peningkatan dan penguatan karakteristik tim kearah yang lebih baik dan peningkatan pengetahuan manajemen yang memadai. Semakin menguatnya dan terbangunnya karakteristik tim dalam pelaksanaannya, diikuti dengan makin terdapatnya pengetahuan manajemen yang memadai, maka akan semakin meningkatkan etika kerja ketua program studi dalam melaksanakan tugas-tugas program studi.

\section{DAFTAR PUSTAKA}

Allan Edward Barskey. 1989. Designing Performance Appraisal Systems, San Francisco: Jossey Bass.

Armstrong, Michael. 2006. Performance Management. London: United Kingdom. 
Berten, Kess, Etika. 1999. Jakarta: PT. Gramedia Pustaka Utama, 1999.

Bloom, Bejamin.S at all. 1984. Taxonomy of Educational Objective, New York: Longman.

Burhanudin Salam, 1997. Etika Sosial:Asas Moral dalam Kehidupan Manusia, Jakarta: Rineka Cipta.

Colquitt, Wasson A, LePine and Wesson. 2009. Organizational Behavior Improving Performance and Commitment in the Work, New York: Mc.Grawhill Companies, Inc.

Daft, Richard L. 2010. New Era Of Management, Ninth Edition, SouthWestern: Cenage Learninig.

Donelly, H. James, at all. 1987. Fundamental of Management. Texas: Business Publication Inc.

Drucker. Peter F. 1990. The New Realities. New York: Harper \& Row Publisher.

Ernawan, Erni. R. 2011. Business Ethichs. Bandung: Alfabeta.

Geral Corey, at all, 2007. Issus and ethics in The Helping Profession, New York: Thoomson Broks.

Gibson. at all, Behavior. 2006. Structure, Proses, New York: Mc-Graw Hill/Irwin Inc.

Griffin, Ricky W. 1990. Management, New Jersey: Texas University, 1990.

Gunnar Myrdal. 1990. Asian Drama An Inquiry Into the Poverty of Nations, New York: Vintage Book.

Good Thomas L and Brophy, Jere. E. 1980. Educational Psychology, New York: Acknowledge.

Ivancevich, John, M. Robert Konopaske, and Michael T. Matteson. 2008.

Organizational Behavior and Management. Eighth edition. New York: McGraw-Hill/Irwin.

James.AF.Stoner, and Edward Freeman. 1996. Management Fith Edition, USA: Prentice-Hall International Edition.

Jujun Suriasumantri. 1999. Ilmu dalam Perspektif, Jakarta: Yayasan Obor Indonesia.

Luthan, Fred. 2008. Organizational Behavior. NewYork: McGraw-Hill Inc.

Luthan and Doh. 2009. International Management Culture, Strategy and Behavior- Sevent Edition, New Yor: M Graw-Hill. 
Mathis, Robert L. dan John H. Jackson. 2002. Manajemen Sumber Daya Manusia, Edisi Pertama, Jakarta: Salemba Empat.

Nelson, Debra L. and James Campbell Quick. 2006. Organizational Behavior. Sosut Western Thomson Coorporation.

Newstrom, Jhon W. 2007. Organizational Behavior. McGraw-Hill: International Edition.

Robins, Sthepen P. 1996. Organizational Behavior: Concept, Controversies, Application, NewJersey: Prentice Hall.

Robins, Stephen P. and Mary Coulter.2009. Management. New Jersey: Prentice-Hall, Inc., Engglewood Cliffs.

Robbin, Stephen P and Timothy A Judge. 2001. Organizational Behavior, New Jersey: Prentice Hill.

Robert Konopaske, Michael T Matteson. 2006. Perilaku Organisasi. Jakarta: Penerbit Erlangga.

Schermerhorn Jr., John R. 1997. Manajemen-Buku 2, terjemahan M. Parnawa Putranta dkk. Yogyakarta: Andi.

Stiffler, Mark A. 2006. Performance Creating the Performance-Driven Organization. USA: Jhon Wiley \& Sons, Inc.

Stoner, J.A.F, et.al. 1996. Manajemen (alih bahasa: Alexander Sindoro), Jakarta: Prenhallindo.

Stoner, James AF.and Edward Freeman. 1989. Manajemen. New Jersey: Prentice Hall Inc.

Vecchio, Robert P. 1995. Organizational Behavior. USA: Harcout Brace and Company.

Veithzal Rivai dan A.Fawzi M. Basri.2005. Performance Appraisals: Sistem yang tepat Untuk Menilai Kinerja Karyawan dan Meningkatkan Daya Saing Perusahaan, Jakarta: Grafindo Persada.

Wagner, John A and Hollenbeck, 1999. Management Organizational Behavior, NewJersey.

Wasson A.Colquit, LePine and Wesson. 2009. Organizational Behavior Improving Performance and Commitment in the Workplace.,New York: Mc.Graw-Hill Companies, Inc.

Zimbardo, G. Philip, at all. 1980. Essential of Psycology. Dallas Texas: Scott, Foresman and Company. 